\title{
Valdivian ecosystems in the Late Cretaceous and Early Tertiary of Antarctica: further evidence from myrtaceous and eucryphiaceous fossil wood
}

\author{
Imogen Poole ${ }^{\mathrm{a}, *}$, Alberta M.W. Mennega ${ }^{\mathrm{a}}$, David J. Cantrill ${ }^{\mathrm{b}}$ \\ a Wood Anatomy Section, National Herbarium of The Netherlands, University of Utrecht Branch, P.O.Box 80102, 3585 CS Utrecht, \\ The Netherlands \\ b Department of Palaeobotany, Swedish Museum of Natural History, Box 50007, S-104 05, Stockholm, Sweden \\ Received 8 February 2002; received in revised form 10 October 2002; accepted 8 November 2002
}

\begin{abstract}
Cool temperate rainforests growing on the flanks of the Andes and along the Coastal Range in Valdivia (Chile) today provide the closest analogue for the fossil floras of Antarctica during the Eocene. This paper records key Valdivian elements in a Maastrichtian to Eocene wood flora that extends the evidence for a Valdivian analogue back as far as possibly the Late Cretaceous. Here we record the first occurrences of myrtaceous and eucryphiaceous wood taxa from the Maastrichtian-Palaeocene sediments of the James Ross Basin. In addition, a previously unrecorded morphotype is described and assigned to the form genus Antarctoxylon which Poole and Cantrill erected for fossil angiosperm woods of Antarctica with uncertain taxonomic affinities. This increases the number and range of the described morphotypes from the Antarctic Peninsula and helps further our understanding of the southern high latitude angiosperm dominated floras.
\end{abstract}

(C) 2003 Elsevier Science B.V. All rights reserved.

Keywords: Cretaceous; Tertiary; Antarctica; fossil wood; Valdivia

\section{Introduction}

Focus on polar ecosystems has gathered momentum over the past few decades since Axelrod (1984) noted that the recognition of the forested polar regions was one of the most important palaeontological discoveries of the last century. Forests existed on the high southern latitudes from the Permian onwards (Taylor et al., 1992) and

\footnotetext{
* Corresponding author. Fax: +31-30-2535307.

E-mail address: i.poole@geo.uu.nl (I. Poole).
}

were only ultimately eradicated through the global climate cooling during the Tertiary (Francis and Poole, 2002; Cantrill, 2001). In the very latest Early Cretaceous the forest ecosystem was dominated by a conifer-fern community similar to that in the warm temperate rainforests of present New Zealand (Falcon-Lang et al., 2001). During the Late Cretaceous flowering plants radiated throughout Gondwana changing the vegetation to one more similar to the angiosperm dominated cool temperate rainforests of Valdivia (southern Chile) today. These Cretaceous forests contain angiosperm elements such as Nothofagaceae, 
Myrtaceae, Lauraceae and Monimiaceae along with conifers belonging to the Cupressaceae, Podocarpaceae and Araucariaceae (Cantrill and Poole, 2002; Poole et al., 2001).

During the Late Mesozoic and Tertiary, eastward subduction of the Pacific Ocean floor beneath the Antarctic Peninsula created an emergent continental arc (Pankhurst and Smellie, 1983; Smellie et al., 1984). Terrestrial deposits preserve a variety of environments containing plant fossils. These range from braided river environments (Nichols and Cantrill, 2002) with in-growth positioned plants (e.g. Cantrill, 1996, 1997) to highenergy volcanic environments with epiclastic and tuffaceous rocks associated with thick sequences of lavas (e.g. on King George Island; Poole et al., 2001). Marine deposits in the James Ross Basin (e.g. Seymour Island and James Ross Island) also contain plants from nearby vegetated land as indicated by the palaeocurrent directions (Pirrie, 1989). Palaeoecological reconstructions, as evidenced from rocks and plants, suggest that widespread volcanic disturbance was the major driving force behind the vegetational changes seen in the Tertiary sequences (Poole et al., 2001).

Climates in the southern high latitudes were generally warmer during the Late Mesozoic-Tertiary than today. A peak of Cretaceous warmth occurs in the Turonian and is followed by cooling events in the Early Campanian and Maastrichtian (Huber, 1998). The Early Palaeogene is marked by warming in the Palaeocene (Upchurch et al., 1998; Zachos et al., 2001) with a peak of warmth in the Early Eocene. Following this peak there is a general climatic deterioration throughout the Tertiary to the present. There is no doubt that this climatic change influenced the vegetational composition although the evolving palaeoenvironments in the Antarctic Peninsula are probably just as important in explaining the causes of the vegetational development. Understanding the natural dynamics of the prevailing ecosystem is paramount to interpreting palaeoenvironments and climate, whether through computer simulated models or from fossil evidence alone. This paper forms part of a research initiative investigating the taxonomic composition of Late Cretaceous and Tertiary floras of the Antarctic Peninsula to further our understanding of the palaeoecological evolution of these southern high latitudes.

\section{Materials and methods}

Considerable research effort over the last 20 years by Argentine, British and American researchers has been dedicated to developing a lithostratigraphic framework for the Early Cretaceous (Aptian) to Tertiary (Miocene) fill of the James Ross Basin. This lithostratigraphic framework forms an important basis for the regional tectonic (Hathway, 2000), palaeoclimatic (e.g. Dingle and Lavelle, 2000) and palaeobiological studies (e.g. Crame et al., 1996). The basinal sequences are divided into four main units, Gustav (Aptian-Coniacian), Marambio (Santonian-Palaeocene), Seymour Island (Palaeocene-earliest Oligocene?) and James Ross Island Volcanic (Miocene-Pliocene) groups. The Marambio Group is subdivided into four formations and this study deals with fossils from the younger of the two formations (the López de Bertodano and Sobral formations) and the overlying Seymour Island Group (La Meseta Formation).

The López de Bertodano Formation was first defined by Rinaldi et al. (1978) and was widely adopted across the James Ross Basin. Recent lithostratigraphic investigations have suggested a more restricted distribution, with the formation being confined to the Seymour, Snow Hill and Vega Islands (Pirrie et al., 1997). The López de Bertodano Formation on Seymour Island was subdivided into ten informal units based on a combination of faunal composition and subsidiary lithological information (Macellari, 1988). The lowermost K1b1 has been assigned to the Haslum Crag Member (Snow Hill Island Formation; Pirrie et al., 1997). The basal unit within the López de Bertodano is a mud-rich unit (K1b2-3 of Macellari, 1988) that weathers to a light grey colour overlain by slightly coarser grained (fine to very fine) muddy sandstones. The López de Bertodano ranges from Middle to Late Maastrichtian through the Cretaceous-Tertiary boundary and into the Early Palaeocene (Danian; Askin, 1988a,b; Huber, 1988). It is overlain unconform- 
ably by the Sobral Formation, a unit that is strongly channelised at the base to such an extent that in places it downcuts up to $100 \mathrm{~m}$ into the underlying López de Bertodano Formation. It is a unit which becomes coarser upwards, at the base composed of brown muds and fine sands that grade upwards into coarse grey sandstones.

The unconformably overlying Seymour Island Group comprises two units: the ?Late Palaeocene Cross Valley Formation and the La Meseta Formation (late Early Eocene to ?earliest Oligocene; Elliot and Trautman, 1982). The stratigraphic relationships of the Cross Valley Formation with the underlying Sobral Formation are complicated. The unit represents an incised channel into the underlying Sobral that was possibly contemporaneous with the deposition of Sobral units Tps $4 / 5$ (Sadler, 1988). A distinct silver shale facies in the upper part of the Cross Valley Formation contains fossil leaves (Dusen, 1908; Case, 1988) and is lithologically similar to facies in Sobral Tps5. The La Meseta Formation represents an incised valley fill that rests unconformably on Cretaceous and Tertiary strata. The formation is internally complicated as it is made up of lenticular muddy sandstone packages that have complicated cut

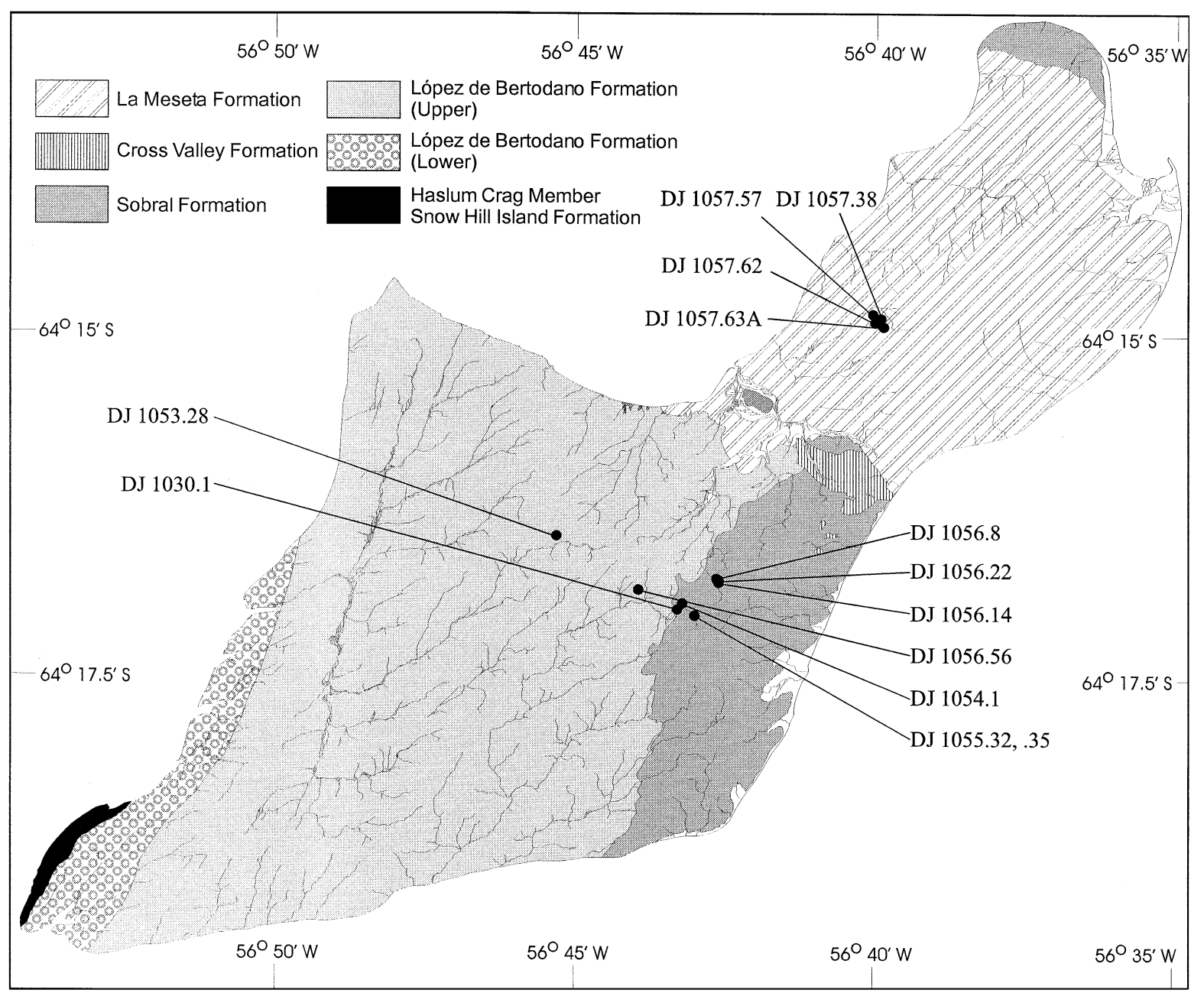

Fig. 1. Map showing the geographical extent of the Cretaceous-Tertiary formations on Seymour Island and the field position of the plant fossil specimens described in the text. 
and fill geometries. Detailed mapping and sedimentological analysis suggests that the La Meseta Formation can be subdivided into six (Marenssi et al., 1998) or seven (Porebski, 1995) units that represent fluctuating base level changes (Porebski, 2000).

All material studied was collected from the López de Bertodano, Sobral and La Meseta Formations on Seymour Island during the 1998-1999 British Antarctic Survey (BAS) field season (Fig. 1). Ages and lithological sequence for the specimens are summarised in Table 1. These specimens supplement those already in the BAS collections. All specimens were found in situ and their stratigraphic position was recorded on detailed sedimentological logs. These logs are housed in the archives of the BAS, Cambridge, UK. The fossil specimens were thin-sectioned and the familial affinities determined as outlined by Poole et al. (2000a) while searches undertaken used the computerised OPCN (Wheeler et al., 1986; LaPasha and Wheeler, 1987) and CSIRO Family Key (Ilic, 1987) wood databases. Comparisons were made with modern material kept in Jodrell Laboratory, Royal Botanic Gardens, Kew, UK, the Institute of Wood Biology and Wood Protection, Hamburg, Germany, and the National Herbarium of The Netherlands (Utrecht University and Leiden
University Branches). The thin-sections and fossil specimens are deposited at the BAS.

\section{Systematic palaeobotany}

Family: Eucryphiaceae

Organ genus: Eucryphiaceoxylon Poole, Mennega et Cantrill gen. nov.

Generic diagnosis: Fossil wood with numerous, predominantly solitary, vessels. Perforation plates scalariform and simple. Intervessel and vessel-ray pitting circular, opposite, transitional and scalariform. Rays non-storied, heterocellular, predominantly uniseriate and biseriate.

Species: Eucryphiaceoxylon eucryphioides (Poole et al., 2001) Poole, Mennega et Cantrill comb. nov.

Basionym: Weinmannioxylon eucryphioides Poole, Hunt et Cantrill, 2001, Annals of Botany, 88: 40, figs. 26, 28, 30-32, 36-38.

Holotype: P.3023.11 (Poole et al., 2001). Repository: British Antarctic Survey, Cambridge, UK.

Table 1

Summary of the fossil specimens collected from Seymour Island with their age, estimated minimum diameter derived from growth ring curvature (B indicates branch/trunk wood of undeterminable diameter) and lithological sequence

\begin{tabular}{|c|c|c|c|c|}
\hline BAS specimen number & Taxonomy & $\begin{array}{l}\text { Diameter } \\
(\mathrm{mm})\end{array}$ & Geological formation & Age \\
\hline & Eucrphiaceoxylon & & & \\
\hline DJ.1057.57 & E. eucryphioides gp 1 & B & La Meseta & Eocene \\
\hline DJ.1057.62 & E. eucryphioides gp 1 & B & La Meseta & Eocene \\
\hline DJ.1055.32 & E. eucryphioides gp 1 & 9 & Sobral & Palaeocene \\
\hline DJ.1057.63A & E. eucryphioides gp 1 & 11 & La Meseta & Eocene \\
\hline DJ.1054.1 & E. eucryphioides gp 2 & 9.5 & Sobral & Palaeocene \\
\hline DJ.1056.14 & E. eucryphioides gp 2 & 6 & Sobral Fm & Palaeocene \\
\hline DJ.1056.22 & E. eucryphioides gp 2 & $\mathrm{~B}$ & Sobral Fm & Palaeocene \\
\hline DJ.1056.56 & E. eucryphioides gp 2 & $\mathrm{~B}$ & López de Bertodano & Palaeocene \\
\hline DJ.1057.38 & $\begin{array}{l}\text { E. eucryphioides gp } 3 \\
\text { Myrceugenelloxylon }\end{array}$ & B & La Meseta & Eocene \\
\hline DJ.1053.28 & M. antarcticus & $\mathrm{B}$ & López de Bertodano & Maastrichtian \\
\hline DJ.1055.35 & M. antarcticus & B & Sobral & Palaeocene \\
\hline DJ.1056.8 & $\begin{array}{l}\text { M. antarcticus } \\
\text { Antarctoxylon }\end{array}$ & 7 & Sobral & Palaeocene \\
\hline DJ.1030.1 & A. juglandoides & 7 & López de Bertodano & Palaeocene \\
\hline
\end{tabular}


Type locality: Fildes Peninsula, King George Island, Antarctica, $62^{\circ} 10^{\prime} \mathrm{S}, 59^{\circ} 04^{\prime} \mathrm{W}$.

Stratigraphic horizon: Middle Unit of the Fildes Formation.

Age of type material: Middle Eocene (i.e. 48-43 Ma; Smellie et al., 1984; Soliani et al., 1988; Fensterseifer et al., 1988; Hunt and Smellie, unpublished data).

Additional material: DJ.1057.62, DJ.1057.57, DJ.1057.63A, DJ. 1055.32 (group 1); DJ.1054.1, DJ.1056.56, DJ.1056.14, DJ.1056.22 (group 2); DJ.1057.38 (group 3).

Species diagnosis: vessels numerous mainly solitary, paired, rarely grouped; mean tangential diameter approximately $55 \mu \mathrm{m}$; mean element length approximately $550 \mu \mathrm{m}$. Perforation plates scalariform with numerous bars, some simple. Intervessel pitting and vessel-ray pitting circular and opposite to horizontally elongate and scalariform. Rays heterocellular, with procumbent body cells and up to two rows of marginal cells; ray height less than $1 \mathrm{~mm}$.

Description: This description is based on nine pieces of calcified fossil branch or trunk wood measuring $>9 \mathrm{~cm}$ for group 1 and $>6 \mathrm{~cm}$ in diameter for group 2 (listed in Table 1). Porosity diffuse porous, occasionally more semi-ring (Plate $\mathrm{I}, 1$ ). Growth rings distinct (indistinct in DJ. 1057.62 and DJ. 1057.63A) and demarcated by a narrow zone of radially flattened fibres and a decrease in vessel diameter and abundance (Plate I, 1). Vessels are more or less circular to radially elliptical in transverse section, occasionally slightly angular (polygonal); solitary, paired or in radial groups of three, rarely four, pores. Mean vessel tangential diameter measures 53.5 $\mu \mathrm{m}$ (range: $23-140 \mu \mathrm{m}$ ) and mean radial diameter measures 62.5 $\mu \mathrm{m}$ (range: 18-289 $\mu \mathrm{m}$ ). Vessel abundance is approximately $153 \mathrm{~mm}^{-2}$ (range: 70-207 $\mathrm{mm}^{-2}$ ). Mean vessel element length measures ca. $530 \mu \mathrm{m}$ (range: 236-885 $\mu \mathrm{m}$ ). Perforation plates are scalariform (Plate I, 8), often with numerous fine bars which are sometimes branched (although one late wood vessel in DJ. 1054.1 was observed to have only four bars to the scalariform perforation plate) and simple (Plate I, 7). Tyloses are often present and can obscure the end plates of the vessels. Intervessel pitting is circular and opposite (ca. $6 \mu \mathrm{m}$ in diameter) to transitional and scalariform $(>10 \mu \mathrm{m}$ in diameter) (Plate $\mathrm{I}$, 5). Vessel-ray pits are generally opposite, circular (Plate I, 10), and often elliptical (ca. $8 \mu \mathrm{m}$ in diameter) in group 1 becoming more horizontally elongate and scalariform (ca. up to $15 \mu \mathrm{m}$ in diameter) in group 2. Rays are uniseriate (ca. 50\%) and biseriate (ca. 50\%) in members of group 1 (Plate II, 2). It should be noted that specimen DJ.1057.57 has a region where triseriate rays are locally abundant but this wood does not appear to be 'normal' (similar to P.3023.10 described by Poole et al., 2001) and may represent tissue associated with a wound response or an emerging lateral - in another tangential section cut from the same specimen this phenomenon was not observed. Group 2 has entirely $(99 \%)$ uniseriate rays (Plate I, 6) whereas the group 3 specimen, DJ.1057.38, has intermittent short, multiseriate rays which are distinctly different from the predominant uniseriate (ca. 70\%) and biseriate (ca. $30 \%$ ) rays giving the impression of rays of two distinct widths (Plate II, 2). Rays are 59-897 $\mu \mathrm{m}$ in height, heterocellular, composed of procumbent body cells with marginal rows of square and upright cells (marginals not observed in group 2 specimens) (Plate I, 9). Dark staining deposits can be seen in some procumbent ray cells in members of P.3023.11 (Plate I, 4) and group 2 (DJ.1056.56, DJ.1054.1). Ray cell walls are predominantly unthickened in members of group 1 but seemingly thickened or pitted in specimens belonging to group 2 . There are 6-15 rays, predominantly 7-11, per mm. Axial parenchyma is difficult to determine in transverse section but can be observed in longitudinal section. Fibres are thin-to-thick walled, non-septate and form the groundmass of the wood. No fibre pitting was observed.

Comparisons: The James Ross Basin specimens assigned to this fossil species can be divided into three subgroups (see above and Table 2). From Table 2 it is obvious that group 2 and the King George Island specimens (prefixed by ' $\mathrm{P}$ ' here and in Poole et al., 2001) show the greatest anatomical similarity and thus can be considered to belong to the same group. Division is predominantly on the basis of ray width although there might also be a 

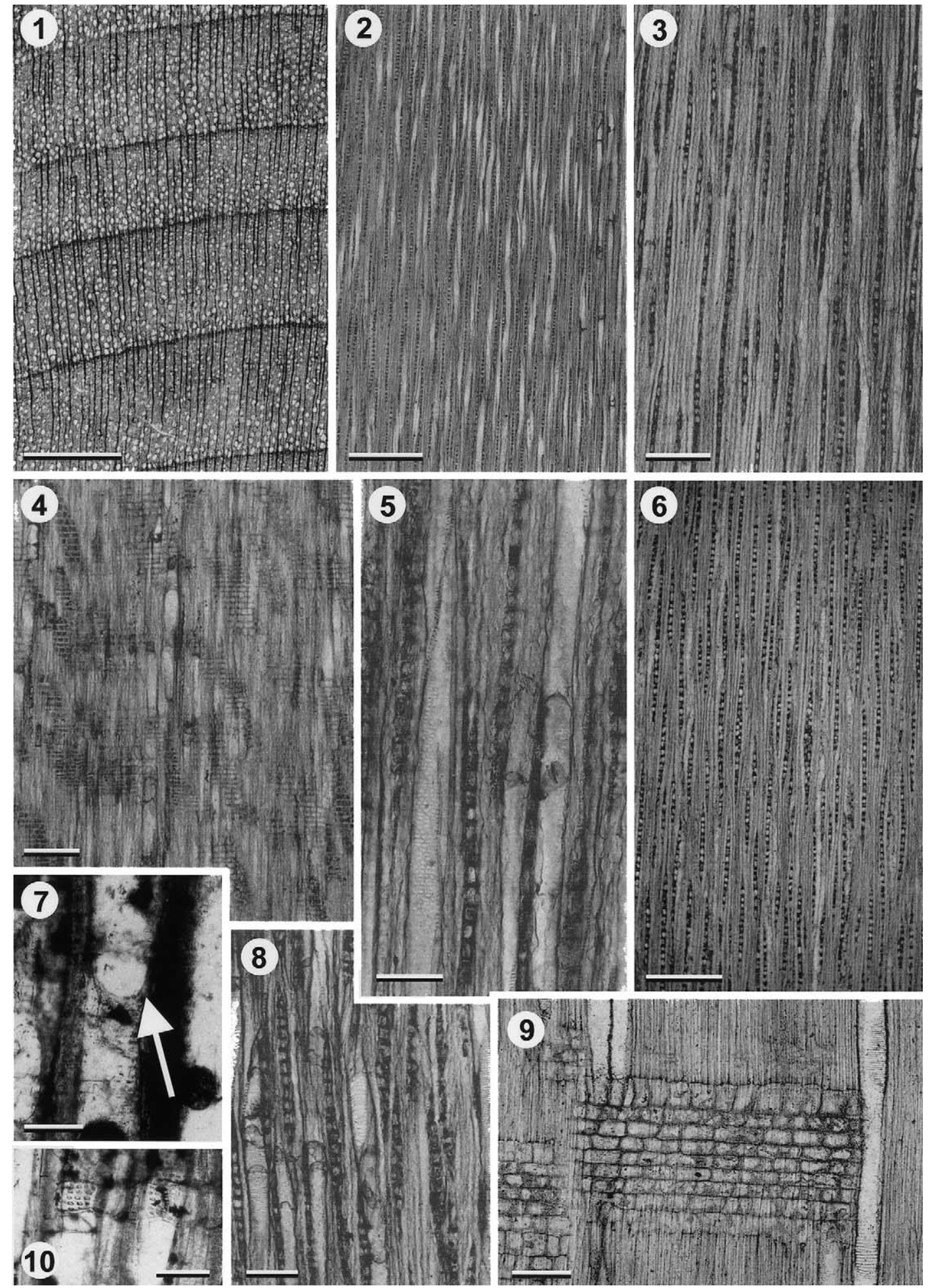
difference in relative abundance of scalariform vs. simple perforation plates (see below). The degree of variation in ray structure (summarised in Table 2 ) is within the natural variation found in modern eucryphiaceous woods although the only exception might be group 3 where none of the modern specimens studied had rays giving the appearance of two distinct widths. However, Metcalfe and Chalk (1950) did document the presence of occasional rays with widths up to 4-6 cells in modern eucryphiaceous wood although Dickison (1978) did not mention seeing this during his survey. Alternatively, the multiseriate rays may indicate the position of emerging laterals.

Based on personal observations, the differences in relative percentage of uniseriate and biseriate rays helps to distinguish the Australian Eucryphia Cav. species from those found in South America today. The Australian species studied, E. moorei F. Muell. and E. lucida Druce, have $>90 \%$ and ca. $75 \%$ biseriate rays, respectively, whereas those from South America, i.e. E. cordifolia Cav. and E. glutinosa Baillon, only total $50 \%$ and $<60 \%$, respectively. It should be noted that there are three additional species of Eucryphia, including E. milliganii (comprised of two subspecies, ssp. milliganii R.W. Barnes, G.J. Jordan, R.S. Hill and C.J. McCoull and E. milliganii ssp. pubescens Barnes, Jordan, Hill and McCoull), E. jinksii Foster and Hyland, and E. wilkiei Foster and Hyland in Australia (Barnes et al., 2000; Foster and Hyland, 1997). The latter two are narrow endemics and thus rare. Wood samples of these species were not available for study. Another study focusing on the comparative anatomy of Eucryphiaceae, was undertaken by Dickison (1978) who recorded that in Eucryphia lucida, E. milliganii Hook. f. and E. moorei (the Australian species) the biseriate ray condition is generally restricted to very localised regions in the ray body whereas those species from Chile have a more extensive multiseriate condition whereby the multiseriate rays have only short uniseriate margins. Ray vessel pitting may help to distinguish between members of groups 1 and 2: those of group 2 have generally more elongate to scalariform pits when compared with the members of group 1. However, no specific mention was given by Dickison (1978) with respect to any difference in ray vessel pitting within the modern species in his survey. No helical thickenings or crystals were observed in the fossil specimens described here, a characteristic feature of all Eucryphia species except E. cordifo$l i a$ and E. glutinosa which lack helical thickenings and E. cordifolia which lacks crystals (Dickison, 1978). The similarity between the specimens in groups 1 and 2 and that assigned to group 3 is overriding except for the presence of the few multiseriate rays and relative abundance of the uniseriate and biseriate rays. Therefore, even though it is uncertain whether the group 3 specimen more closely resembles wood of modern Eucryphia not yet available for study, or another, as yet unexplored but otherwise anatomically very similar, taxon, this specimen is included within this form genus but recognised as a separate group for the purposes of identification.

The second feature that helps to distinguish the

Plate I. Light micrographs of Eucryphiaceoxylon eucryphioides gen. nov., nov. comb.

1. Transverse section (TS) of P.3023.11 showing distinct growth rings and vessel distribution; scale bar $=1 \mathrm{~mm}$.

2. Tangential longitudinal section (TLS) of P.3023.11 showing multiseriate ray distribution; scale bar $=500 \mu \mathrm{m}$.

3. TLS of P.3023.11 showing constituent ray cells; scale bar $=200 \mu \mathrm{m}$.

4. Radial (R) LS of P.3023.11 showing ray distribution; scale bar $=250 \mu \mathrm{m}$.

5. TLS of P.3023.11 showing intervessel pits; scale bar $=75 \mu \mathrm{m}$.

6. TLS of P.3023.11 showing rare biseriate rays; scale bar $=500 \mu \mathrm{m}$.

7. RLS of DJ.1057.38 showing simple perforation plate; scale bar $=75 \mu \mathrm{m}$.

8. TLS of P.3023.11 showing scalariform perforation plates; scale bar $=100 \mu \mathrm{m}$.

9. RLS of P.3023.11 showing predominantly procumbent cells forming the body of the ray and one row of more square to upright marginal cells; scale bar $=100 \mu \mathrm{m}$

10. RLS of DJ.1054.01 showing the vessel-ray pits; scale bar $=50 \mu \mathrm{m}$. 

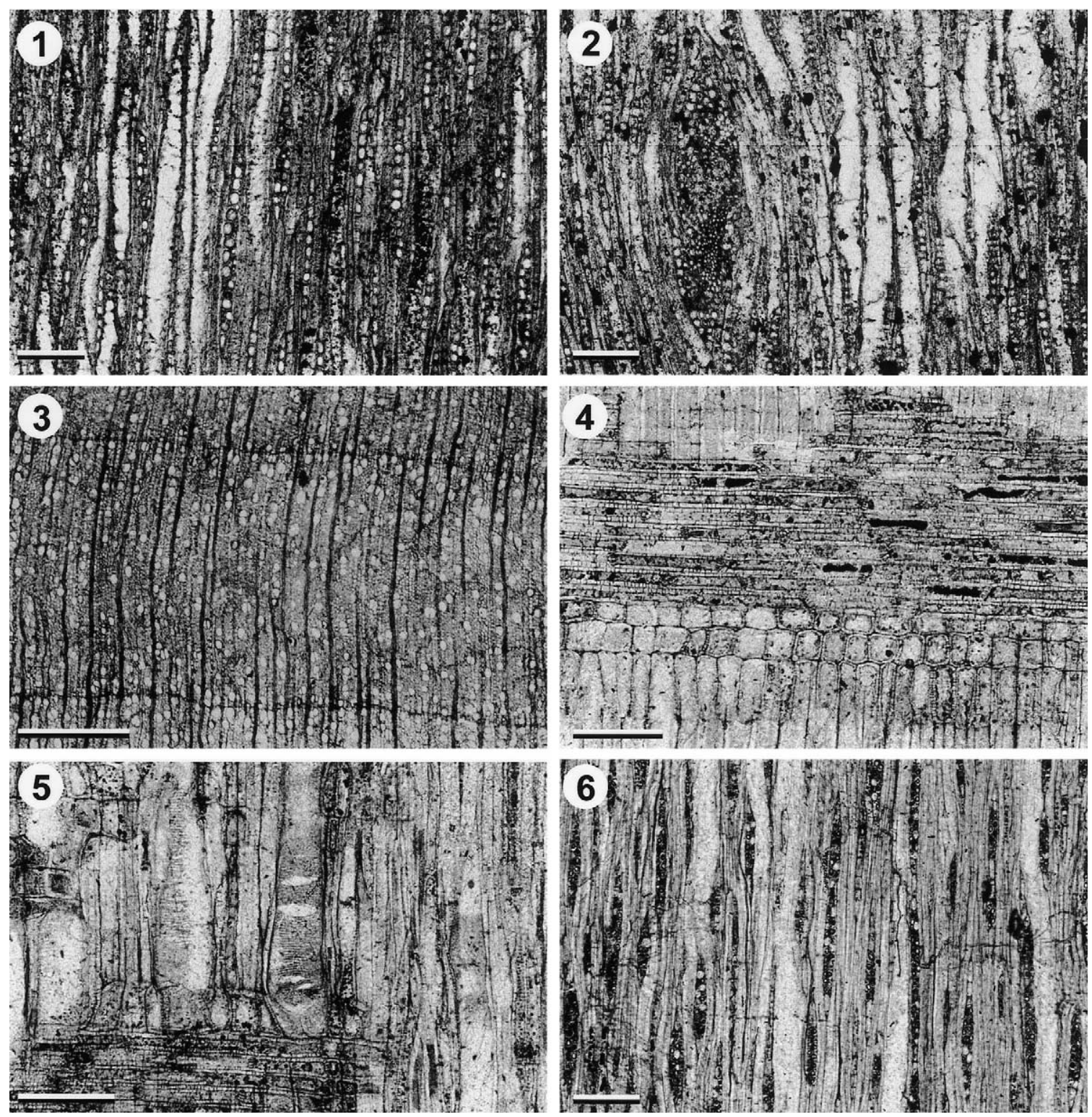

Plate II. Light micrographs of Eucryphiaceoxylon eucryphioides gen. nov., nov. comb. (1 and 2) and Myrceugenelloxylon antarcticus (3-6).

1. TLS of DJ.1057.57 (group 1) showing uniseriate and biseriate rays; scale bar $=100 \mu \mathrm{m}$.

2. TLS of DJ.1057.38 (group 3) showing predominantly uniseriate rays and rarely multiseriate rays; scale bar $=150 \mu \mathrm{m}$.

3. TS of DJ.1055.35; scale bar $=500 \mu \mathrm{m}$.

4. RLS of DJ.1055.35 showing the procumbent, pitted cells forming the body of the ray; scale bar $=100 \mu \mathrm{m}$.

5. RLS of DJ.1055.35 showing the scalariform perforation plates; scale bar $=100 \mu \mathrm{m}$

6. TLS of DJ.1055.35 showing predominantly biseriate rays sometimes axially united; scale bar $=150 \mu \mathrm{m}$. 
Table 2

Comparison of three possible eucryphiaceous wood groups from the Maastrichtian and Palaeocene of Seymour Island with the type species Eucryphiaceoxylon eucryphioides (Poole, Hunt et Cantrill, 2001) comb. nov. and unpublished Eucryphioxylon fildense (Torres, 1990) from the Eocene of King George Island

\begin{tabular}{|c|c|c|c|c|c|}
\hline \multirow[t]{2}{*}{ Feature } & \multicolumn{5}{|c|}{ Eucryphiaceae: Eucryphiaceoxylon } \\
\hline & $\begin{array}{l}\text { E. eucryphioides comb. } \\
\text { nov. }\end{array}$ & E. eucryphioides gp. 1 & E. eucryphioides gp. 2 & E. eucryphioides gp. 3 & $\begin{array}{l}\text { 'Eucryphioxylon fildense' } \\
\text { (unpublished) }\end{array}$ \\
\hline Growth rings & distinct & distinct (indistinct) & distinct & distinct & distinct \\
\hline Vessels no. $(\mathrm{mm})^{-2}$ & $103(67-179)$ & $154(124-184)$ & $107(70-158)$ & $198(184-207)$ & $40-59$ \\
\hline - range $V \varnothing t \mu \mathrm{m}$ (range) & $49(25-105(-200))$ & $47(23-140)$ & $58(23-136)$ & $56(27-122)$ & $30-125$ \\
\hline - mean $\mathrm{V} \varnothing \mathrm{r} \mu \mathrm{m}$ (range) & $64(17.5-95(-187.5))$ & $52(18-125)$ & $75(27-172(289))$ & $46(18-95)$ & - \\
\hline - mean VEL $\mu \mathrm{m}$ (range) & $714(620-1160)$ & $555(236-861)$ & $551(366-885)$ & $484(189-649)$ & $500-700$ \\
\hline - cross sectional shape & circular-elliptic & circular-elliptic (polygonal) & circular-elliptic (polygonal) & circular-elliptic & circular-elliptic \\
\hline - distribution & solitary, paired, groups & solitary, paired, groups & solitary, paired, groups & $\begin{array}{l}\text { solitary, paired, groups } \\
\text { (radial) }\end{array}$ & solitary, paired, groups \\
\hline - porosity & $\begin{array}{l}\text { diffuse to weakly } \\
\text { semiring }\end{array}$ & diffuse & diffuse (weakly semiring) & diffuse & diffuse \\
\hline - perforation plates & scalariform, simple & scalariform, rarely simple & scalariform, rarely simple & scalariform, simple & scalariform, simple \\
\hline $\begin{array}{l}\text { - intervessel pitting } \\
\text { - tyloses }\end{array}$ & $\begin{array}{l}\text { (opposite-) scalariform } \\
\text { present }\end{array}$ & $\begin{array}{l}\text { scalariform } \\
\text { (present) }\end{array}$ & $\begin{array}{l}\text { opposite-scalariform } \\
\text { present }\end{array}$ & $\begin{array}{l}\text { scalariform } \\
\text { present }\end{array}$ & $\begin{array}{l}\text { transitional } \\
\text { present }\end{array}$ \\
\hline Rays & $\begin{array}{l}\text { uniseriate (ca. 95\%), } \\
\text { partly biseriate (ca. } 5 \% \text { ) }\end{array}$ & $\begin{array}{l}\text { uniseriate }(50 \%) \text {, biseriate } \\
(50 \%)\end{array}$ & $\begin{array}{l}\text { uniseriate }(99 \%) \text {, biseriate } \\
(1 \%)\end{array}$ & $\begin{array}{l}\text { uniseriate }(70 \%) \text {, biseriate } \\
(\text { ca. } 30 \%) \text {, occasionally } \\
\text { multiseriate }(6 \text { cells, } \\
\text { ca. }<1 \%)\end{array}$ & $\begin{array}{l}\text { uniseriate }(26 \%) \text {, biseriate } \\
(66 \%) \text {, rarely triseriate }(8 \%)\end{array}$ \\
\hline - height $(\mu \mathrm{m})$ & $120-910$ & $59-826$ & $106-897$ & $106-448$ & ca. $50-740$ ( $2-28$ cells $)$ \\
\hline - ray vessel pitting & $\begin{array}{l}\text { elongate-scalariform } \\
\text { (circular) }\end{array}$ & circular-scalariform & $\begin{array}{l}\text { circular-horizontally } \\
\text { elongate }\end{array}$ & circular-scalariform & circular, elliptical, elongate \\
\hline - contents & none observed & none observed & $\begin{array}{l}\text { rare brown staining } \\
\text { deposits }\end{array}$ & $\begin{array}{l}\text { rare brown staining } \\
\text { deposits }\end{array}$ & none observed \\
\hline - marginals (no. rows) & upright (1-2) & square-upright (1-2) & none observed & square-upright (1-2) & none observed \\
\hline - body & procumbent & procumbent & procumbent & procumbent & procumbent \\
\hline - walls & pitted/thickened & unpitted/unthickened & pitted/thickened & unpitted/unthickened & ?unthickened \\
\hline Parenchyma & ?diffuse & none observed & none observed & none observed & diffuse, rarely \\
\hline Fibres & non-septate & non-septate & non-septate & non-septate & non-septate \\
\hline - walls & thin & thin-to-thick & thin-to-thick & thin-to-thick & thin-to-thick \\
\hline - pitting & none observed & none observed & none observed & none observed & none observed \\
\hline
\end{tabular}

Group 1 includes DJ. 1055.32, DJ. 1057.62, DJ. 1057.57, DJ. 1057.63A; group 2 includes DJ. 1056.56, DJ. 1054.1, DJ. 1056.14, DJ. 1056.22; group 3 includes DJ. 1057.38; see text for details. 
James Ross Island wood groups from each other is the relative abundance of scalariform and simple perforation plates. Both plate types are recorded in the Chilean Eucryphia cordifolia. The situation is less distinct for E. glutinosa where not all the specimens of this species examined show this character state (Dickison, 1978). Only exclusively scalariform perforation plates, or almost so, are seen in the Australian species (Rancusi et al., 1987; Gregory, 1998). From Table 2 it can be seen that the members of group 3 have both scalariform and simple perforations present in more equal proportions whereas the members of group 1 and 2 have seemingly more scalariform perforation plates and only rarely simple perforations to the vessel elements. Nevertheless, any further separation of these three fossil groups into separate taxa, based predominantly on one character, with the degree of variation similar to that seen within the modern genus, cannot be justified at this stage.

Other eucryphiaceous wood fossils have been described from Antarctica apart from those mentioned above. Torres (1990) described two fossils from the Eocene of King George Island in her doctoral thesis and erected a new genus, 'Eucryphioxylon', for her material. Unfortunately, this work has not been validly published for nomenclatural purposes, and this taxon is invalid. Consequently, a new organ genus, Eucryphiaceoxylon, has been erected here to accommodate those fossils with anatomy most similar to extant Eucryphia. The King George Island specimens previously assigned to Weinmannioxylon eucryphioides by Poole et al. (2001) are transferred to this newly erected organ taxon because they are distinguishable from other members of Weinmannioxylon described from South America and Antarctica by ray characters and entirely scalariform perforation plates (see Poole et al., 2000a). These characters are sufficiently distinct, in the light of recent findings of similar specimens from the James Ross Basin, to erect a new fossil taxon.

When the specimens assigned to Eucryphiaceoxylon are compared with those described by Torres (1990) clearer anatomical distinctions can be made: vessel abundance is considerably less than $100 \mathrm{~mm}^{-2}$ (Table 2), which differs from modern eucryphiaceous woods which have high (i.e. $>100 \mathrm{~mm}^{-2}$ ) pore numbers (Dickison, 1978), and up to $8 \%$ of the rays in Torres' specimens are triseriate (Table 2). On the basis of ray structure these specimens seem to have the closest similarity to those of group 1 herein. Only with reexamination of Torres' material will it become clear whether these characters are sufficiently distinct to warrant the erection of a new species of Eucryphiaceoxylon to accommodate them.

\section{Family: Myrtaceae}

Organ genus: Myrceugenelloxylon Nishida, 1984a.

Species: Myrceugenelloxylon antarcticus Poole, Hunt et Cantrill, 2001.

Material studied: DJ. 1056.8, DJ. 1055.35, DJ. 1053.28

Description: Based on three pieces of calcified fossil branch or trunk wood measuring $>7 \mathrm{~cm}$ in diameter (Table 1). Porosity diffuse porous (Plate II, 3). Growth rings distinct to indistinct demarcated by zones of radially flattened fibres (Plate II, 3) and a decrease in vessel diameter and abundance. Vessels are more or less circular to radially elliptical in transverse section with flattened contact faces; solitary or paired. Mean vessel tangential diameter measures $57 \mu \mathrm{m}$ (range: $23-121 \mu \mathrm{m}$ ) and mean radial diameter measures $61 \mu \mathrm{m}$ (range $18-163 \mu \mathrm{m})$. Vessel abundance is approximately $102 \mathrm{~mm}^{-2}$ (range: $74-138 \mathrm{~mm}^{-2}$ ). Mean vessel element length measures $494 \mu \mathrm{m}$ (range: 260 $696 \mu \mathrm{m}$ ). Perforation plates scalariform with numerous fine bars (Plate II, 5). In one specimen (DJ.1053.28) simple perforation plates may also be present. Tyloses are present in DJ.1053.28 only and can obscure the end plates of the vessels. Intervessel pitting is circular to horizontally elongate, and ca. $5 \mu \mathrm{m}$ in diameter. Ray-vessel pits number up to 15 per cross field and are small, opposite, circular to horizontally elongate, up to $5 \mu \mathrm{m}$ in diameter and possibly bordered. Rays are uniseriate, predominately biseriate (Plate II, 4; DJ. 1053.28) or triseriate (DJ. 1056.8, DJ. 1055.35), sometimes quadriseriate (DJ.1056.8); 
Table 3

Comparison of the three species of Myrceugenelloxylon: the type species Myrceugenelloxylon pseudoapiculatum (Nishida, 1984a,b), and Myrceugenelloxylon maytenoides (Nishida, Nishida et Nasa) comb. nov. Poole et al. (2001), and Myrceugenelloxylon antarcticus described by Poole et al. (2001) and fossils described herein

\begin{tabular}{|c|c|c|c|c|}
\hline \multirow[t]{2}{*}{ Feature } & \multicolumn{4}{|c|}{ Myrceugenelloxylon Nishida 1984a } \\
\hline & $\begin{array}{l}\text { M. pseudoapiculatum } \\
\text { Nishida 1984a }\end{array}$ & $\begin{array}{l}\text { M. maytenoides } \\
\text { (Nishida, Nishida et Nasa 1988) } \\
\text { Poole et al. } 2001\end{array}$ & $\begin{array}{l}\text { M. antarcticus } \\
\text { Poole Hunt et Cantrill } 2001\end{array}$ & $\begin{array}{l}\text { M. antarcticus } \\
\text { herein }\end{array}$ \\
\hline Growth rings & indistinct & distinct & distinct & distinct (indistinct) \\
\hline Vessels no. $\mathrm{mm}^{-2}$ & $19(15-27)$ & $430(200-590)$ & $88(77-102)$ & $102(74-138)$ \\
\hline - mean $\mathrm{V} \varnothing \mathrm{t} \mu \mathrm{m}$ (range) & $-(100-150)$ & $42.5(17-66)$ & $54(37.5-67.5)$ & $57(23-121)$ \\
\hline - mean $\mathrm{V} \varnothing \mathrm{r} \mu \mathrm{m}$ (range) & $-(110-180)$ & $54.6(24-88)$ & $84(50-122.5)$ & $61(18-163)$ \\
\hline - mean VEL $\mu \mathrm{m}$ (range) & $1100-1400$ & - & $714(620-1160)$ & $494(260-696)$ \\
\hline - cross sectional shape & circular-elliptical & circular-elliptical & circular-elliptical & circular-elliptical \\
\hline - distribution & $\begin{array}{l}\text { solitary, some pairs, rarely } \\
\text { groups }\end{array}$ & solitary & solitary, some pairs, rarely groups & solitary or paired \\
\hline - porosity & diffuse & diffuse & diffuse & diffuse \\
\hline - perforation plates (bars) & scalariform (5-8) & scalariform (14-60), reticulate & scalariform (numerous) & scalariform (numerous) \\
\hline - intervessel pitting & $\begin{array}{l}\text { circular to elliptical, } \\
\text { scalariform or alternate }\end{array}$ & $\begin{array}{l}\text { circular to elliptical, opposite, } \\
\text { rarely scalariform }\end{array}$ & $\begin{array}{l}\text { circular, mainly horizontally } \\
\text { elongate and scalariform }\end{array}$ & $\begin{array}{l}\text { circular to horizontally } \\
\text { elongate }\end{array}$ \\
\hline - contents & abundant tyloses & abundant tyloses & tyloses absent & tyloses generally absent \\
\hline Rays & $\begin{array}{l}2-3 \text {, rarely uniseriate or } \\
\text { quadriseriate }\end{array}$ & $2-3$ seriate, occasionally uniseriate & biseriate, rarely uniseriate & $\begin{array}{l}\text { bi- or triseriate, some uni- } \\
\text { or quadriseriate }\end{array}$ \\
\hline - height $\mu \mathrm{m}$ & (200-) 450-700 (-1350) & $86-618$ & $(50-) 300-400(-700)$ & $47-519$ \\
\hline - ray vessel pitting & circular and bordered & circular to elliptical & circular, elongate to transitional & circular to elongate \\
\hline - contents & large oil cells & absent & dark staining deposit & absent \\
\hline - marginals: no. rows, shape & $\begin{array}{l}- \text {, upright, few } \\
\text { interconnecting }\end{array}$ & $\begin{array}{l}2-10 \text {, upright, some } \\
\text { interconnecting }\end{array}$ & $\begin{array}{l}\text { up to } 6-8(500 \mu \mathrm{m}) \text {, upright, some } \\
\text { interconnecting }\end{array}$ & $\begin{array}{l}\text { up to } 13 \text {, square, upright, } \\
\text { some interconnecting }\end{array}$ \\
\hline - body cells & procumbent & procumbent & procumbent & procumbent \\
\hline - walls & pitted & pitted & thickened/pitted & thickened/pitted \\
\hline Parenchyma & none observed & apotracheal, diffuse & ?diffuse & none observed \\
\hline Fibres & non-septate & non-septate & non-septate & predominantly non-septate \\
\hline - walls & thick & thin-to-thick & thin-to-thick & thin \\
\hline - pitting & none observed & - & none observed & bordered \\
\hline
\end{tabular}



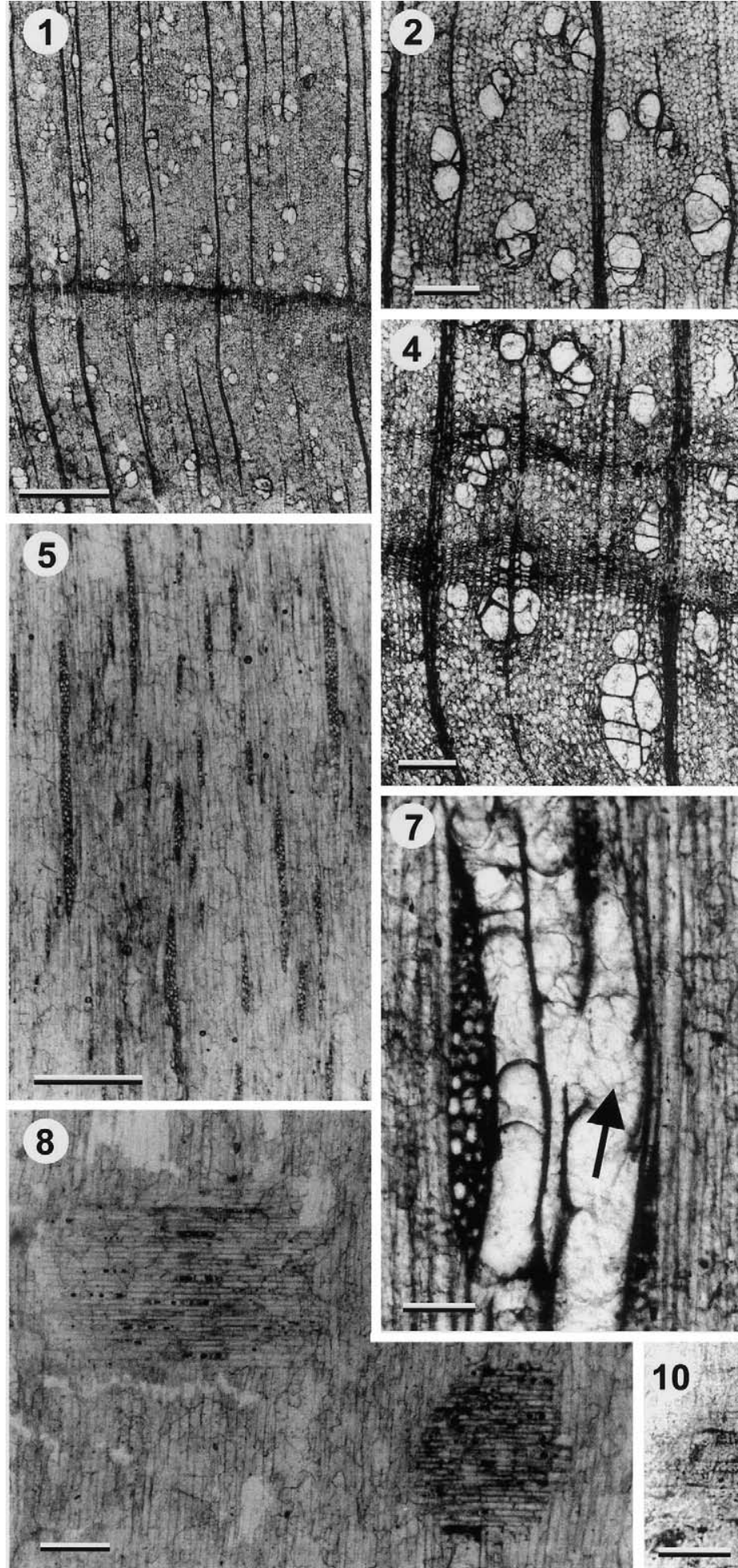
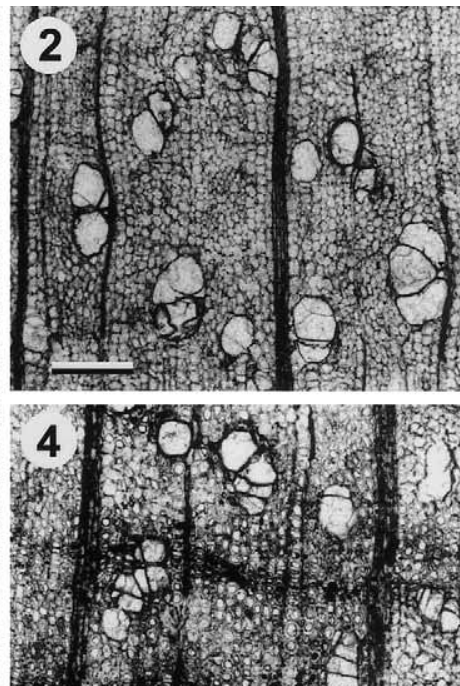

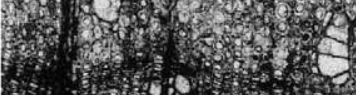
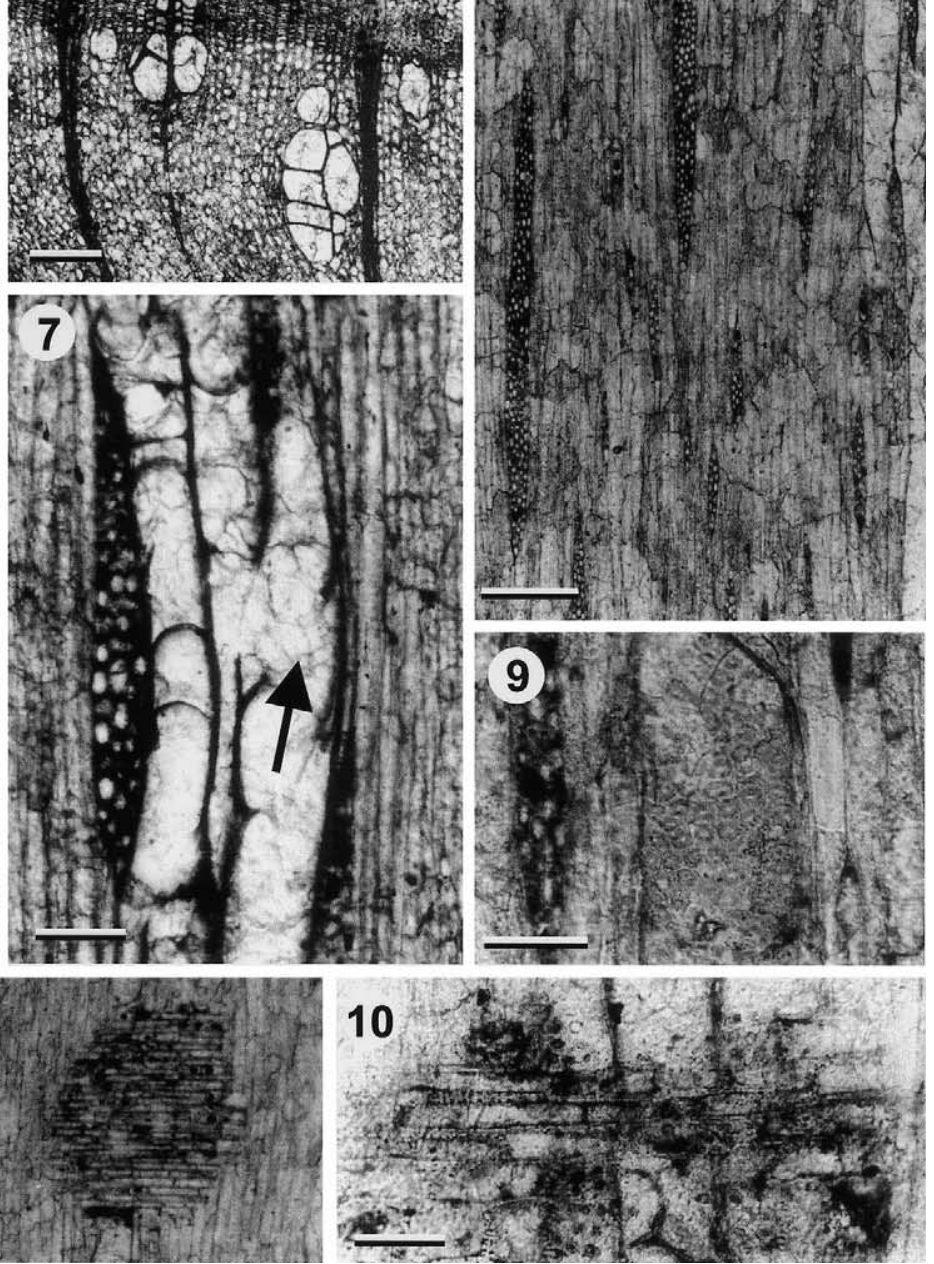
some multiseriate rays interconnect. Heterocellular rays measure $47-519 \mu \mathrm{m}$ in height and are composed of procumbent body cells with 1-8 (sometimes up to 13) rows of square and upright marginal cells (Plate II, 4). Ray cell walls pitted (or seemingly thickened; Plate II, 4). There are 317, predominantly $7-12$, rays per mm. Axial parenchyma is possibly diffuse but often not observed in transverse section. Fibres are thin-tothick walled, forming the groundmass of the wood. In DJ.1056.8 fibre pitting is ca. $5 \mu \mathrm{m}$, bordered and arranged in uniseriate rows. Septae within the fibres have only been observed in DJ.1053.28.

Comparisons: Myrtaceous woods have been recorded from the Tertiary of King George Island, Antarctica, by Poole et al. (2001) (see Table 3). These fossils are anatomically very similar to extant Luma A. Gray (Myrtaceae) and were assigned to the species Myrceugenelloxylon antarcticus. The woods described herein show close anatomical similarity to $M$. antarcticus, differing only in the presence of rare triseriate rays in specimen DJ.1055.35 and rays predominantly triseriate in DJ.1056.8. However, this variation in ray width is seen in other members of Myrceugenelloxylon found in South America (Nishida, 1984a; Nishida et al., 1988). Septate fibres seen in DJ. 1053.28 and probably also in DJ.1055.35 have not been recorded with respect to members of this form genus although they are documented in some modern Myrtaceous woods from South America (Rancusi et al., 1987). The differences noted here between $M$. antarcticus from the Eocene of King George Island and those from the Maastrichtian and Palaeocene from Seymour Island are not considered great enough to warrant separation into a separate taxon at this stage.

Of the myrtaceous woods found today in southern South America Myrceugenia O. Berg. and Myrceugenella (DC) Kaus appear very similar to the fossils. They differ from the other members of the family predominantly in vessel characters which include the presence of simple and scalariform perforation plates, scalariform to opposite intervessel pits and predominantly apotracheal parenchyma (Rancusi et al., 1987). Some similarity can be seen with species of Ackama A. Cunn. such as Ackama muelleri Benth. of the Cunoniaceae in that the biseriate rays have uniseriate marginal cells forming wings of the same thickness as the biseriate body (see Dadswell and Eckersley, 1938, plate II). However, in addition to these rays $A$. muelleri also has 3-6 seriate rays and scalariform ray-vessel pits which differ from the fossils described here. Fossils with anatomical similarity to modern Ackama are known from the Antarctic and do differ substantially in overall anatomy (Poole and Cantrill, 2001).

\section{Incertae Sedis}

Organ genus: Antarctoxylon Poole et Cantrill, 2001

Species: Antarctoxylon juglandoides Poole, Mennega et Cantrill sp. nov.

Holotype: DJ. 1030.1

Plate III. Light micrographs of Antarctoxylon juglandoides sp. nov.

1. TS showing distinct growth ring and vessel distribution; scale bar $=500 \mu \mathrm{m}$.

2. TS showing vessels in pairs and groups of three, not necessarily entirely radially orientated; scale bar $=150 \mu \mathrm{m}$.

3. TS showing radial groups of vessels linearly orientated; scale bar $=100 \mu \mathrm{m}$.

4. TS showing distinct growth ring and ?false ring; scale bar $=100 \mu \mathrm{m}$.

5. TLS showing ray distribution; scale bar $=500 \mu \mathrm{m}$.

6. TLS showing cellular detail of rays; scale bar $=150 \mu \mathrm{m}$.

7. TLS showing simple perforation plate (arrowed) and tyloses in vessels; scale bar $=100 \mu \mathrm{m}$.

8. RLS showing procumbent rays cells; scale bar $=250 \mu \mathrm{m}$.

9. TLS showing intervessel pits; scale bar $=50 \mu \mathrm{m}$.

10. RLS showing ray vessel pitting; scale bar $=50 \mu \mathrm{m}$. 
Repository: British Antarctic Survey, Cambridge, UK.

Type locality: Seymour Island, Antarctica, $64^{\circ} 15^{\prime} 53^{\prime \prime} \mathrm{S}, 56^{\circ} 45^{\prime} 1^{\prime \prime} \mathrm{W}$.

Stratigraphic horizon: López de Bertodano Formation, Palaeocene.

Etymology: the specific epithet recognises the similarity this fossil shares with extant Juglans but does not imply biological affinity.

Species diagnosis: Fossil wood with distinct growth rings. Diffuse porous. Vessels small, clustered into groups of 3-6, rarely solitary and paired. Perforation plates simple. Intervessel pits alternate. Rays heterocellular predominantly $2-5$ cells wide and $<1 \mathrm{~mm}$ in height; rarely uniseriate and $<0.5 \mathrm{~mm}$ in height. Fibres non-septate.

Description: This description is based on one piece of calcified branch wood with an estimated diameter of $7 \mathrm{~cm}$. Porosity diffuse (Plate III, 1). Growth rings distinct and demarcated by zones of radially flattened fibres (Plate III, 1, 4). Possible false rings present (Plate III, 4). Vessels are more or less circular to radially elliptical in transverse section with flattened contact faces, solitary, paired or in radial files of ca. 6, and clusters of up to 10 pores (Plate III, 3 and 4 ). Mean vessel tangential diameter measures $65 \mu \mathrm{m}$ (range: 26$107 \mu \mathrm{m})$ and mean radial diameter measures 67 $\mu \mathrm{m}$ (range 15.5-104 $\mu \mathrm{m}$ ). Vessel abundance is approximately $28 \mathrm{~mm}^{-2}$ (range: 23-31 mm $\mathrm{mm}^{-2}$ ). Mean vessel element length measures $449 \mu \mathrm{m}$ (range: $320-700 \mu \mathrm{m}$ ). Perforation plates are simple (Plate III, 7). Tyloses are present (Plate III, 7) and often obscure the end plates of the vessels. Intervessel pits are bordered, alternate (ca. $5 \mu \mathrm{m}$ in diameter), sometimes sub-opposite, circular rather than polygonal in outline, 9-12.5 $\mu \mathrm{m}$ in diameter (Plate III, 9). Vessel-ray pits are generally opposite, circular (5 $\mu \mathrm{m}$ in diameter) and often more elliptical (ca. $13 \mu \mathrm{m}$ in diameter) (Plate III, 10). Rays non-storied, mainly multiseriate, of 2 to predominantly 4 (rarely 5) cells wide and $150-850 \mu \mathrm{m}$ in height (Plate III, 5 and 6). Multiseriate rays are heterocellular, composed of procumbent body cells (Plate III, 8) with 1-2 rows of more square to upright marginal cells, very occasionally there are ca. 3 taller (each up to $100 \mu \mathrm{m}$ ) marginal cells which give the appearance of short wings to a few of the rays. Intermittent cells resembling sheath cells can be determined in longitudinal section. Uniseriate rays are composed of tall $(>45 \mu \mathrm{m})$ upright cells and do not exceed a total height of $375 \mu \mathrm{m}$. Ray cell walls are sometimes slightly thickened (?pitted); cells with dark staining deposits (Plate III, 8). There are 5-8 rays per $\mathrm{mm}$. Axial parenchyma is difficult to detect (the walls of the fibres are thin thus making the distinction between parenchyma and fibre cells difficult) but seem to be diffuse or diffuse in aggregate. Fibres form the ground mass but are not arranged in radial rows. Fibres have a mean tangential diameter of ca. $11 \mu \mathrm{m}$ (range: $8-16 \mu \mathrm{m}$ ) and a mean radial diameter of ca. $14 \mu \mathrm{m}$ (range: 8-23 $\mu \mathrm{m}$ ). Mean radial wall thickness of the fibres measured ca. $5.5 \mu \mathrm{m}$ (range: $4-8 \mu \mathrm{m}$ ). No fibre pitting was observed.

Comparisons: This wood morphotype has proved to be difficult to identify because of its unusual combination of (1) multiseriate rays ( $2-4$ seriate), some with uniseriate wings composed of up to three cells each measuring a maximum of 100 $\mu \mathrm{m}$; (2) small-diameter $(<100 \mu \mathrm{m})$ vessels which are more or less circular and arranged in both radial groups usually of $2-3$ pores and more or less recurved and clustered groups of up to 10 pores; (3) simple perforation plates; and (4) alternate intervessel pits. These characters distinguish it from other fossil woods described from Antarctica to date. Other fossil woods have been described which show superficial similarity to this fossil. Paraphyllanthoxylon Bailey, with a record extending back to the Albian, also has simple perforation plates, groups of vessels, relatively few vessels per square $\mathrm{mm}$, but differ in the size, abundance and grouping of the vessels, presence of septate fibres and the enlarged vessel-ray pits that characterise species of this genus (see e.g. Herendeen, 1991; Meijer, 2000 and references therein).

Comparisons were made with all available sections of families which were highlighted as being similar by computer database output. These included: Actinidiaceae, Annonaceae, Araliaceae, Capparidaceae, Bombacaceae, Elaeocarpaceae, Ericaceae, Juglandaceae, Leguminosae, Moraceae, some Rutaceae and Solanaceae, Sterculia- 
ceae, Tiliaceae, and Ulmaceae. Within these families certain taxa did show good similarity although this tended to be restricted to one plane of section only; none were convincing in all three planes. The greatest similarity was seen with $J u$ glans L. of the Juglandaceae. However, the Juglandaceae have much larger diameter vessels that are thus less abundant. The groups of vessels are more linearly orientated in Juglans when compared with the fossil. All other characters are relatively similar. When other fossil juglandaceous type wood material was compared (e.g. Manchester, 1983; Dupéron, 1988 and references therein; Gottwald, 1992; Wheeler and Landon, 1992; Manchester and Wheeler, 1993) the similarities become more tenuous. The description of Clarnoxylon Manchester and Wheeler (1993) probably gives the greatest similarity between fossil juglandaceous woods with the Antarctic material but the latter lacks idioblasts with rhomboidal crystals associated with the rays, and radial multiples of vessels. Therefore, we have assigned the wood to Antarctoxylon, a form genus erected by Poole and Cantrill (2001) for fossil angiosperm woods from Antarctica with uncertain taxonomic affinities.

\section{Discussion}

Evidence from both the rocks and fossil plants of Antarctica play an integral role in understanding the biodiversity and palaeoecology, including palaeoclimate, at southern high latitudes during the final phases of the break up of the Gondwanan supercontinent. The Antarctic Peninsula was originally thought to have provided the gateway for angiosperm migration across Gondwana following the highly disturbed environments associated with the rift valley systems which accompanied Gondwanan breakup (Dettmann, 1989). However, new evidence suggests that the Antarctic Peninsula was not the main gateway, at least in the early stages of Gondwana radiation, and that India and Africa were probably involved (Cantrill and Poole, 2002).

Angiosperms do not seem to have arrived in Antarctica before the Early Albian, thus postdat- ing angiospermous evidence elsewhere in eastern Gondwana (e.g. Burger, 1981, 1990, 1993; Taylor and Hickey, 1990). Patterns of floristic replacement, abundant angiospermous pollen and the lack of fossil wood in the Antarctic Peninsula at this time suggest that the early angiosperms were amongst the understorey and coloniser element of the vegetation. This is a pattern similar to that seen elsewhere in the world. A later angiosperm invasion occurred in the overstorey with the appearance of tree species as attested to by abundant wood in the Late Cretaceous sequences.

Palaeoecological reconstructions as evidenced from rocks and plants suggest that widespread volcanic disturbance was the major driving force behind the vegetational changes in Antarctica during the Eocene (Poole et al., 2001). Here a vegetation type very similar (ca. $85 \%$ ) to that of the Valdivian rainforests of southern Chile is thought to have prevailed. Characteristic elements such as Nothofagaceae, Myrtaceae, Eucryphiaceae, Lauraceae, Monimiaceae, Cupressaceae, and Podocarpaceae have already been documented from the macrofossil floras of the South Shetland Islands (Poole et al., 2001 and references therein). Now eucryphiaceous and myrtaceous elements have been found in the earlier wood flora of Seymour Island some $4^{\circ}$ latitude to the south and some $20 \mathrm{Ma}$ earlier. These two elements can be added to other components of a Valdivian-like vegetation such as the Monimiaceae, Cunoniaceae, Lauraceae, Araucariaceae, Podocarpaceae, Cupressaceae, Cyatheaceae, and Dicksoniaceae derived from the earlier Maastrichtian-Palaeocene wood, pollen and leaf assemblages from this more southerly geographical region (see Askin, 1992; Hill and Scriven, 1995; Poole and Francis, 1999, 2000; Poole et al., 2000a,b,c; Poole and Gottwald, 2001; Cesari et al., 2001) suggestive of a Valdivian rainforest-type vegetation extending across the Peninsula region and into South America throughout the Late Cretaceous and Tertiary. If this is the case, then the changes in vegetational composition during the Late Cretaceous and Tertiary have to be discussed in the context of widespread ecological disturbance and subsequent vegetational succession set against a 
backdrop of general climatic deterioration rather than solely climate induced vegetational change.

The importance of wood records from the Antarctic in furthering our understanding of the origins and development of the Southern Hemisphere flora cannot be overemphasised. Phylogenetic studies of extant families are increasingly using fossil evidence to provide information on minimum ages for nodes nested within phylogenetic trees (as a way of testing the validity of the tree and also for testing biogeographic hypotheses). This study provides an Early Palaeocene age for eucryphiaceous fossils suggesting an earlier origin for this austral group than previous studies (cf. Late Palaeocene leaf macrofossils from Antarctica; Barnes and Jordan, 2000). Eucryphia has an extensive fossil record in southeastern Australia, with macrofossil evidence extending back to the Late Palaeocene (Hill, 1991; Taylor and Hill, 1996; Barnes and Jordan, 2000; Barnes et al., 2001). However, this pattern of earlier occurrence of austral groups in Antarctica than elsewhere in the Southern Hemisphere has been noted before with respect to other groups such as Lophosoriaceae (Dettmann, 1986; Cantrill, 1998), Nothofagaceae (Dettmann, 1989), Proteaceae (Askin, 1989; Dettmann and Jarzen, 1991), and with respect to genera within the Cunoniaceae such as Weinmannia, which occurs from the Late Cretaceous in Antarctica (e.g. Poole et al., 2000a; Cranwell, 1959), but does not appear until the Oligocene in Australia (see Barnes et al., 2001). This paper also documents the first record of myrtaceous fossil wood in Antarctica, although the family has already been recorded in pollen (e.g. Dettmann, 1989; Askin, 1992; Dutra and Batten, 2000) and possible leaf assemblages (Birkenmajer and Zastawniak, 1986; Hayes, 1999) in the Peninsula region dating back to the Early Campanian. Other fossil records of myrtaceous woods in the Southern Hemisphere come principally from Tertiary deposits in southern South America (Rangonese, 1980; Nishida, 1984a,b; Nishida et al., 1988) and from the Late Tertiary of Australia (e.g. Bishop and Bamber, 1985; Rowell et al., 2001).

Results such as these are not just of value to palaeobotanists. Computer generated modelling studies of climates through geological time are gathering momentum. Important prerequisites to these models, amongst others, is the knowledge of vegetation-atmosphere interactions (Upchurch et al., 1998). If the Cretaceous and Tertiary vegetation of Antarctica can be understood more fully, then simulations using realistic ecosystems and ecosystem distribution will provide models of greater precision and accuracy. The vegetation type can only be gained from the fossil plant record and therefore advances in computer modelling must go hand in hand with advances in ecosystem reconstruction and biodiversity studies based on fossil plant material through the geological past.

\section{Conclusions}

This paper documents the earliest occurrences of myrtaceous and eucryphiaceous types of wood from Antarctica and thus extends their record back into the Maastrichtian and Early Palaeocene, respectively. In addition, a third morphotype is described from the Palaeocene which superficially resembles extant members of the Juglandaceae but is assigned to the form genus Antarctoxylon for fossil angiosperm woods with uncertain affinities. The presence of myrtaceous and eucryphiaceous elements in the earliest Tertiary fossil floras provides further evidence for a spatially and temporally extensive Valdivian type ecosystem. With continued studies of the angiosperm wood flora of Antarctica these floral types can be added and the Valdivian model refined, thus enabling a greater understanding of the origins and evolution of the modern austral vegetation. Moreover, greater understanding of the palaeo-vegetation that existed across Antarctica will aid studies focusing on palaeoclimatology using computer-generated models.

\section{Acknowledgements}

I.P. wishes to thank the BAS for the loan of the fossil wood specimens and for the invitation to collect further material. Professor H. Gottwald 
and Dr. R. Barnes are acknowledged for useful discussions. We appreciate the help of Drs. P. Rudall and H. Richter as well as Professor P. Baas in allowing access to the modern wood slide collections housed at Jodrell Laboratory, Royal Botanic Gardens, the Institute for Wood Biology and Wood Protection, Hamburg, and the National Herbarium of The Netherlands, University of Leiden Branch, respectively. D.J.C. would like to thank the BAS for their support in the initial stages of this investigation. In particular, we would also like to thank M. Tabecki (BAS) for his continued help in preparing the thin-sections. We are grateful to Professors R.S. Hill and R.A. Askin for their thorough reviews. Dr. J. Francis is thanked for her assistance in the field which included the collection of specimen DJ.1030.1. The preliminary stages of this research were undertaken whilst in receipt of NERC funding (Grant GR3/11088) which is here gratefully acknowledged.

\section{References}

Askin, R.A., 1988a. The palynological record across the Cretaceous/Tertiary transition on Seymour Island, Antarctica. Geol. Soc. Am. Mem. 169, 155-162.

Askin, R.A., 1988b. Campanian to Paleocene palynological sucession of Seymour and adjacent islands, northeastern Antarctic Peninsula. Geol. Soc. Am. Mem. 169, 131-153.

Askin, R.A., 1989. Endemism and heterochroneity in the Late Cretaceous (Campanian) to Paleocene palynofloras of Seymour Island, Antarctica: Implications for origins, dispersals and palaeoclimates of southern floras. In: Crame, J.A. (Ed.), Origins and Evolution of the Antarctic Biota. Geol. Soc. Lond. Spec. Pub. 47, pp. 107-119.

Askin, R.A., 1992. Late Cretaceous-Early Tertiary Antarctic outcrop evidence for past vegetation and climates. Antarct. Res. Ser. 56, 61-73.

Axelrod, D.J., 1984. An interpretation of Cretaceous and Tertiary biota in polar regions. Palaeogeogr. Palaeoclimatol. Palaeoecol. 45, 105-147.

Barnes, R.W., Jordan, G.J., 2000. Eucryphia (Cunoniaceae) reproductive and leaf macrofossils from Australian Cainozoic sediments. Aust. Syst. Bot. 13, 373-394.

Barnes, R.W., Hill, R.S., Bradford, J.C., 2001. The history of Cunoniaceae in Australia from macrofossil evidence. Aust. J. Bot. 49, 301-320.

Barnes, R.W., Jordan, G.J., Hill, R.S., McCoull, C.J., 2000. A common boundary between distinct northern and southern morphotypes in two unrelated Tasmanian rainforest species. Aust. J. Bot. 48, 481-491.

Birkenmajer, K., Zastawniak, E., 1986. Plant remains from the Dufayel Island Group (early Tertiary?), King George Island, South Shetland Islands (West Antarctica). Acta Palaeobot. 26, 33-54.

Bishop, P., Bamber, R.K., 1985. Silicified wood of Early Miocene Nothofagus, Acacia and Myrtaceae (aff. Eucalyptus B) from the upper Lachlan valley, New South Wales. Alcheringa 9, 221-228.

Burger, D., 1981. Observations on the earliest angiosperms development with special reference to Australia. Proc. Fourth Int. Palynol. Conf., 3, Lucknow, pp. 418-428.

Burger, D., 1990. Early Cretaceous angiosperms from Queensland, Australia. Rev. Palaeobot. Palynol. 65, 153-163.

Burger, D., 1993. Early and middle Cretaceous angiosperm pollen grains from Australia. Rev. Palaeobot. Palynol. 78, 183-234.

Cantrill, D.J., 1996. Fern thickets from the Cretaceous of Alexander Island, Antarctica containing Alamatus bifarius Douglas and Aculea acicularis sp. nov.. Cretac. Res. 17, 169-182.

Cantrill, D.J., 1997. Hepatophytes from the Cretaceous of Alexander Island, Antarctica: systematics and ecology. Int. J. Plant Sci. 158, 476-488.

Cantrill, D.J., 1998. Early Cretaceous fern foliage referable to Lophosoriaceae from President Head, Snow Island, Antarctica. Alcheringa 22, 241-258.

Cantrill, D.J., 2001. Early Oligocene Nothofagus from CRP-3, Antarctica: Implications for the vegetation history. Terra Antarct. 8, 401-406.

Cantrill, D.J., Poole, I., 2002. Cretaceous patterns of floristic change in the Antarctic Peninsula. Geol. Soc. Lond. Spec. Pub. 194, 141-152.

Case, J.A., 1988. Paleogene floras from Seymour Island, Antarctic Peninsula. Geol. Soc. Am. Mem. 169, 523-530.

Cesari, S.N., Marenssi, S.A., Santillana, S.N., 2001. Conifers from the Upper Cretaceous of Cape Lamb, Vega Island, Antarctica. Cretac. Res. 22, 309-319.

Crame, J.A., Lomas, S.A., Pirrie, D., Luther, A., 1996. Late Cretaceous extinction patterns in Antarctica. J. Geol. Soc. Lond. 153, 503-506.

Cranwell, L.M., 1959. Fossil pollen from Seymour Island, Antarctica. Nature 184, 1782-1785.

Dadswell, H.E., Eckersley, A.M., 1938. The wood structure of some Australian Cunoniaceae with methods for identification. CSIRO Bull. 119, 1-23.

Dettmann, M.E., 1986. Significance of the Cretaceous-Tertiary spore genus Cyatheacidites in tracing the origin and migration of Lophosoria (Filicopsida). Spec. Pap. Paleontol. 35, 63-94.

Dettmann, M.E., 1989. Antarctica: Cretaceous cradle of austral temperate rainforests? In: Crame, J.A. (Ed.), Origins and Evolution of the Antarctic Biota. Geol. Soc. Lond. Spec. Pub. 47, pp. 89-105.

Dettmann, M.E., Jarzen, D.M., 1991. Pollen evidence for Late 
Cretaceous differentiation of Proteaceae in southern polar forests. Can. J. Bot. 69, 901-906.

Dickison, W.C., 1978. Comparative anatomy of Eucryphiaceae. Am. J. Bot. 65, 722-735.

Dingle, R.V., Lavelle, M., 2000. Antarctic Peninsula Late Cretaceous-Early Cenozoic palaeoenvironments and Gondwana palaeogeographies. J. Afr. Earth Sci. 31, 91-105.

Dupéron, J., 1988. Les bois fossiles de Juglandaceae: inventaire et revision. Rev. Palaeobot. Palynol. 53, 251-282.

Dusen, P., 1908. Die Tertiare flora der Seymour-Insel. Wiss. Ergeb. Schwed. Sudpolar-Exped. 1901-1903 3, 1-27.

Dutra, T.L., Batten, D.J., 2000. Upper Cretaceous floras of King George Island, West Antarctica, and their phytogeographic implications. Cretac. Res. 21, 181-209.

Elliot, D.H., Trautman, T.A., 1982. Lower Tertiary strata on Seymour Island. In: Craddock, C. (Ed.), Antarctic Geoscience. Univ. Wisconsian Press, Madison, pp. 287-297.

Falcon-Lang, H.J., Cantrill, D.J., Nichols, G.J., 2001. Biodiversity and terrestrial ecology of a mid-Cretaceous, highlatitude floodplain, Alexander Island, Antarctica. J. Geol. Soc. Lond. 158, 709-724.

Fensterseifer, H.C., Soliani, E., Hansen, M.A.F., Troian, F.L., 1988. Geología e estratigrafía da associação de rochas do setor centro-norte da peninsula Fildes, Ilha Rei George, Shetland do Sul, Antártica. Ser. Cìent. Inst. Àntart. Chileno 38, 29-43.

Foster, P.I., Hyland, B.P.M., 1997. Two new species of Eucryphia Cac. (Cunoniaceae) from Queensland. Austrobaileya 4, 589-596.

Francis, J.E., Poole, I., 2002. Cretaceous and Tertiary climates of Antarctica: evidence from fossil wood. Palaeogeogr. Palaeoclimatol. Palaeoecol. 182, 47-64.

Gottwald, H., 1992. Hölzer aus Marinen Sanden des Oberen Eozän von Helmstedt (Niedersachsen). Palaeontographica B 225, 27-103.

Gregory, M., 1998. Eucryphiaceae. In: Cutler, D.F., Gregory, M. (Eds.), Anatomy of the Dicotyledons, IV. Saxifragales. Clarendon Press, Oxford, pp. 35-40.

Hathway, B., 2000. Continental rift to back-arc basin: Jurassic-Cretaceous stratigraphical and structural evolution of the Larsen Basin, Antarctic Peninsula. J. Geol. Soc. Lond. 157, 417-432.

Hayes, P.A., 1999. Cretaceous Angiosperm Floras of Antarctica. Unpubl. Ph.D. Thesis, Univ. of Leeds.

Herendeen, P.S., 1991. Lauraceous wood from the mid-Cretaceous Potomac group of eastern North America: Paraphyllanthoxylon marylandense sp. nov. Rev. Palaeobot. Palynol. 69, 277-290.

Hill, R.S., 1991. Leaves of Eucryphia (Eucryphiaceae) from Tertiary sediments in south-eastern Australia. Aust. Syst. Bot. 4, 481-497.

Hill, R.S., Scriven, L.J., 1995. The angiosperm dominated woody vegetation of Antarctica: a review. Rev. Palaeobot. Palynol. 86, 175-198.

Huber, B.T., 1988. Upper Campanian-Paleocene foraminifera from the James Ross Island region, Antarctic Peninsula. Geol. Soc. Am. Mem. 169, 163-252.
Huber, B.T., 1998. Tropical paradise at the Cretaceous Poles? Science 282, 2199-2200.

Ilic, J., 1987. The CSIRO Family Key for Hardwood Identification. Brill, Leiden.

LaPasha, C.A., Wheeler, E.A., 1987. A microcomputer bases system for computer-aided wood identification. IAWA Bull. 8, 347-354.

Macellari, C.E., 1988. Stratigraphy, sedimentology, and palaeoecology of Upper Cretaceous/Paleogene shelf-deltaic sediments of Seymour Island. Geol. Soc. Am. Mem. 169, $25-53$.

Manchester, S.R., 1983. Fossil wood of the Engelhardieae (Juglandaceae) from the Eocene of North America: Engelhardioxylon gen. nov. Bot. Gaz. 144, 157-163.

Manchester, S., Wheeler, E.A., 1993. Extinct juglandaceous wood from the Eocene of Oregon and its implications for xylem evolution in the Juglandaceae. IAWA J. 14, 103111.

Marenssi, S.A., Santillana, S.N., Rinaldi, C.A., 1998. Paleoambientes sedimentarios de la Aloformacion La Meseta (Eoceno), Isla Marambio (Seymour), Antartica. Contrib. Inst. Antart. Argent. 464, 1-51.

Meijer, J.J.F., 2000. Fossil wood from the Late Cretaceous Aachen Formation. Rev. Palaeobot. Palynol. 112, 297 336.

Metcalfe, C.R., Chalk, L., 1950. Anatomy of the Dicotyledons, 1 and 2. Clarendon Press, Oxford.

Nichols, G.J., Cantrill, D.J., 2002. Sedimentology and revised stratigraphy of the upper part of a Mesozoic forearc basin succession, Alexander Island, Antarctica. Geol. Mag. 139, 313-330.

Nishida, M., 1984a. The anatomy and affinities of the petrified plants from the Tertiary of Chile, III. Petrified woods from Mocha Island, Central Chile. In: Nishida, M. (Ed.), Contributions to the Botany of the Andes, 1. Academia Scientific Books, Tokyo, pp. 98-110.

Nishida, M., 1984b. The anatomy and affinities of the petrified plants from the Tertiary of Chile, IV. Dicotyledonous woods from Quiriquina Island near Concepción. In: Nishida, M. (Ed.), Contributions to the Botany of the Andes, 1. Academia Scientific Books, Tokyo, pp. 111-141.

Nishida, M., Nishida, H., Rancusi, M.H., 1988. Notes on the petrified plants from Chile (I). J. Jpn. Bot. 63, 39-48.

Pankhurst, R.J., Smellie, J.L., 1983. K-Ar geochronology of the South Shetland Islands, Lesser Antarctica: Apparent lateral migration of Jurassic to Quaternary island arc volcanism. Earth Planet. Sci. Lett. 66, 214-222.

Pirrie, D., Crame, J.A., Lomas, S.A., Riding, J.B., 1997. Late Cretaceous stratigraphy of the Admiralty Sound region, James Ross Basin, Antarctica. Cretac. Res. 18, 109-137.

Pirrie, D., 1989. Shallow marine sedimentation within an active margin basin, James Ross Basin, Antarctica. Sediment. Geol. 63, 61-82.

Poole, I., Cantrill, D.J., 2001. Fossil woods from Williams Point Beds, Livingston Island, Antarctica: a Late Cretaceous southern high latitude flora. Palaeontology 44, 10811112 . 
Poole, I., Francis, J.E., 1999. The first record of fossil atherospermataceous wood from the upper Cretaceous of Antarctica. Rev. Palaeobot. Palynol. 107, 97-107.

Poole, I., Francis, J.E., 2000. The first record of fossil wood of Winteraceae from the Upper Cretaceous of Antarctica. Ann. Bot. 85, 307-315.

Poole, I., Gottwald, H., 2001. Monimiaceae sensu lato, an element of Gondwanan polar forests: Evidence from the Late Cretaceous-early Tertiary wood flora of Antarctica. Aust. Syst. Bot. 14, 207-230.

Poole, I., Cantrill, D.J., Hayes, P., Francis, J.E., 2000a. The fossil record of Cunoniaceae: new evidence from Late Cretaceous wood of Antarctica? Rev. Palaeobot. Palynol. 111, $127-144$.

Poole, I., Gottwald, H., Francis, J.E., 2000b. Illiciaceae, an element of Gondwanan polar forests? Late Cretaceous and Early Tertiary woods of Antarctica. Ann. Bot. 86, 421-432.

Poole, I., Richter, H., Francis, J.E., 2000c. Gondwanan origins for Sassafras (Lauraceae)? evidence from Late Cretaceous fossil wood of Antarctica. IAWA J. 21, 463-475.

Poole, I., Hunt, R.J., Cantrill, D.J., 2001. A fossil wood flora from King George Island: ecological implications for an Antarctic Eocene vegetation. Ann. Bot. 88, 33-54.

Porebski, S., 1995. Facies architecture in a tectonically-controlled incised-valley estuary: La Meseta Formation (Eocene) of Seymour Island, Antarctic Peninsula. Studia Geol. Polonica 107, 7-97.

Porebski, S., 2000. Shelf-valley compound fill produced by fault subsidence and eustatic sea-level changes, Eocene La Meseta Formation, Seymour Island, Antarctica. Geology 28, 147-150.

Rancusi, M., Nishida, M., Nishida, H., 1987. Xylotomy of important Chilean woods. In: Nishida, M. (Ed.), Contributions to the Botany of the Andes, 2. Academia Scientific Books, Tokyo, pp 68-158.

Rangonese, A.M., 1980. Lenos fosiles de dicotiledoneas del Paleoceno de Patagonia, Argentina. Ameghiniana 17, $297-$ 311.

Rinaldi, C.A., Massabie, A., Morelli, J., Rosenman, H.L., del Valle, R.A., 1978. Geologia de la isla Vicecomodoro Marambio. Contrib. Inst. Antart. Argent. 217, 1-44.
Rowell, M.V., Jordan, G.J., Barnes, R.W., 2001. An in situ Late Pleistocec Melaleuca fossil forest at Coal Head, western Tasmania, Australia. Aust. J. Bot. 49, 235-244.

Sadler, P.M., 1988. Geometry and stratification of uppermost Cretaceous and Paleogene units on Seymour Island, northern Antarctic Peninsula. Geol. Soc. Am. Mem. 169, 303320.

Smellie, J.L., Pankhurst, R.J., Thomson, M.R.A., Davies, R.E.S., 1984. The geology of the South Shetland Islands, VI. Stratigraphy, geochemistry and evolution. Brit. Antarct. Surv. Sci. Rep. 87, 1-85.

Soliani, E., Kawashita, K., Fensterseifer, H., Hansen, M.A., Troian, F., 1988. K-Ar ages of the Winkel Point Formation (Fildes Peninsula Group) and associated intrusions, King George Island, Antarctica. S. Cìent. Inst. Àntart. Chileno 38, 133-139.

Taylor, D.W., Hickey, L.J., 1990. An Aptian plant with attached leaves and flowers: implication for angiosperm origin. Science 247, 702-704.

Taylor, E.L., Taylor, T.N., Cuneo, N.R., 1992. The present is not the key to the past: a polar forest from the Permian of Antarctica. Science 257, 1675-1677.

Taylor, F., Hill, R.S., 1996. A phylogenetic analysis of the Eucryphiaceae. Aust. Syst. Bot. 9, 735-748.

Torres, T. 1990. Etude paleobotanique du Tertiaire des Iles Roi Georges et Seymour, Antarctique. Unpubl. Ph.D. Thesis, Univ. Claude Bernard, Lyon.

Upchurch, G.R., Otto-Bliesner, B.L., Scotese, C., 1998. Vegetation-atmosphere interactions and their role in global warming during the latest Cretaceous. Philos. Trans. R. Soc. Lond. B 353, 97-112.

Wheeler, E.A., Landon, J., 1992. Late Eocene (Chadronian) dicotyledonous woods from Nebraska: evolutionary and ecological significance. Rev. Palaeobot. Palynol. 74, 267282.

Wheeler, E.A., Pearson, R.G., LaPasha, C.A., Zack, T., Hatley, W., 1986. Computer-aided Wood Identification. N.C. Agric. Res. Serv. Bull. 474, Raleigh.

Zachos, J.C., Pagani, M., Sloan, L., Thomas, E., Billups, K., 2001. Trends, rhythms, and aberrations in global climate 65 Ma to present. Science 292, 686-693. 